\title{
Restricting detergent protease action to surface of protein fibres by chemical modification
}

Received: 12 August 2005 / Revised: 23 January 2006 / Accepted: 24 January 2006 / Published online: 4 April 2006

C) Springer-Verlag 2006

\begin{abstract}
Due to their excellent properties, such as thermostability, activity over a broad range of $\mathrm{pH}$ and efficient stain removal, proteases from Bacillus sp. are commonly used in the textile industry including industrial processes and laundry and represent one of the most important groups of enzymes. However, due to the action of proteases, severe damage on natural protein fibres such as silk and wool result after washing with detergents containing proteases. To include the benefits of proteases in a wool fibre friendly detergent formulation, the soluble polymer polyethylene glycol (PEG) was covalently attached to a protease from Bacillus licheniformis. In contrast to activation of PEG with cyanuric chloride $(50 \%)$ activation with $1,1^{\prime}$-carbonyldiimidazole (CDI) lead to activity recovery above $90 \%$. With these modified enzymes, hydrolytic attack on wool fibres could be successfully prevented up to $95 \%$ compared to the native enzymes. Colour difference $(\Delta E)$ measured in the three
\end{abstract}

\footnotetext{
M. Schroeder · A. Kandelbauer · G. M. Gübitz $(\bowtie)$ Department of Environmental Biotechnology,

Graz University of Technology,

Petersgasse 12,

A-8010 Graz, Austria

e-mail: guebitz@tugraz.at

Tel.: +43-316-8738312

Fax: +43-316-8738819

H. B. M. Lenting

Department of Coating and Surface Engineering,

Textile Group, TNO,

Jan van Galenstraat 21,

7511 JL, Enschede, The Netherlands
}

\section{A. Kandelbauer}

Kompetenzzentrum Holz GmbH,

c/o Department of Applied Research,

Funder Industrie Gesellschaft,

Klagenfurterstrasse 87-89,

A-9300 St.-Veit, Austria

C. J. S. M. Silva · A. Cavaco-Paulo

Department of Textile Engineering, University of Minho,

4800 Guimarães, Portugal dimensional colour space showed good stain removal properties for the modified enzymes. Furthermore, half-life of the modified enzymes in buffers and commercial detergents solutions was nearly twice as high as those of the non-modified enzymes with values of up to $63 \mathrm{~min}$. Out of the different modified proteases especially the $B$. licheniformis protease with the $2.0-\mathrm{kDa}$ polymer attached both retained stain removal properties and did not hydrolyse/damage wool fibres.

\section{Introduction}

Highly efficient stain removal at low temperatures and low water consumption are the main ecological benefits of enzymes in detergent formulations. Enhancing the action of surfactants and improving the performance for shorter cycle times increased the applications of enzymes in the textile industry since the late sixties (Galante and Formantici 2003). Among the different enzymes used in detergency such as amylases, lipases, cellulases and mannanases, proteases are one of the most important groups of industrial enzymes. Removing a variety of stains based on proteins including egg, milk, sauces, grass, blood, proteases are present in nearly all kinds of laundry and automatic dishwashing detergents (Maurer 2004; Egmont 2005).

Alkaline proteases from Bacillus licheniformis are one of the first representatives for detergent proteases, used for 40 years and are still of industrial relevance. Bacterial proteases are mostly easily produced, thermo stable and active over a broad range of $\mathrm{pH}$. Due to these excellent properties and the successful genetic engineering approaches in the 1980s, subtilisins from Bacillus sp., wild types and recombinant strains, provide all the proteases used in the detergent industry nowadays (Maurer 2004).

A great challenge for proteolytic detergent formulations is the stain removal on natural fibres such as wool and silk. In contrast to other proteases, detergent proteases act on a wide range of proteins (different stains). This low substrate specificity is also responsible for their main disadvantage, 
causing severe damage on protein fibres. For obvious reasons, hydrolysis of wool fibres by proteases resulted in high strength and weight losses (Heine and Höcker 1995; Shen et al. 1999). Subtilisins usually used in detergents have a size of approximately $27 \mathrm{kDa}$ (Maurer 2004) and are able to penetrate into the fibre easily and destroy the cortex involving a reduced tensile strength. Therefore, a restriction of the enzyme activity onto the wool surface and diffusion control is required. It has been previously shown that increasing the molecular weight by attaching synthetic polymers onto the enzyme could restrain the action range of protease to the outer part of wool fibres providing an anti-shrinking effect (Schroeder et al. 2004).

Chemical modification of proteins with polyethylene glycol (PEG) is widely used due to a plenitude of useful properties: very low toxicity, excellent solubility in aqueous and organic media and extremely low immunogenic behaviour (Dosio et al. 2001). Major applications of PEG conjugates are the stabilisation of protein in aqueous media leading to increased half-life (Besson et al. 1995; Yang et al. 1996; Kodera et al. 1998), improvement of solubility and stability in organic solvent (Hernáiz et al. 1997; Kwon et al. 1999; Koops et al. 1999) and improvement of characteristics of therapeutic proteins (Veronese 2001; Roberts et al. 2002)

In the following study, the potential of PEG-modified proteases with different molecular weights as an additive for wool detergent is demonstrated for the first time. Although we have previously reported on the chemical modification of a protease from Bacillus lentus for wool anti-shrinking treatment (Schroeder et al. 2004), this enzyme was not suitable for stain removal. Thus, proteases from $B$. licheniformis known for a wide substrate range were modified by attaching the enzyme covalently to methoxy polyethylene glycol to design a proteolytic enzyme for stain removal from wool fabrics which is not damaging for wool fibres. For this purpose, two different modification strategies were compared.

\section{Materials and methods}

\section{Materials}

The alkaline protease from $B$. licheniformis and B. lentus were supplied by Novozymes (Bagsvaerd, Denmark) and Genencor (Leiden, The Netherlands), respectively. The protease was purified by gel filtration, using a Superdex 200 HiLoad 16/60 column (Amersham Pharmacia, Uppsala, Sweden), detection at $280 \mathrm{~nm}$ and a phosphate buffer $(0.1 \mathrm{M}, \mathrm{pH} 7.0)$ as eluent.

Wool fibres (approximately $23 \mu \mathrm{m}$ in diameter) and yarns of wool fibres were supplied by Drummond Parkland of England. These yarns have been used for the construction of knitted fabric using a Stoll CMS 330 knitting machine (right-right knitting [1×1] with two yarns; number of needles/in.: seven; stitch: 9.5). Yellow coloured woollen carpet was kindly donated by James (the Netherlands). All other chemicals and solvents were of analytical grade.
Synthesis of the B. licheniformis protease conjugates

In brief, $0.8 \mathrm{mmol}$ of methoxypolyethylene glycol [molecular weight (M.W.) 5,000] from Fluka was dissolved in $100 \mathrm{ml}$ of dried toluene and activated with $2.4 \mathrm{mmol}$ cyanuric chloride (CC) from Sigma in the presence of $60 \mathrm{mmol}$ sodium carbonate anhydrous and $6.0 \mathrm{~g}$ molecular sieves A4. After stirring for $40 \mathrm{~h}$ at $40^{\circ} \mathrm{C}$, the mixture was centrifuged to discard the precipitate and precipitated in $300 \mathrm{ml}$ of petroleum ether. The reaction was monitored by thin-layer chromatography (TLC) (silica gel, eluent: methanol/chloroform 1:4) (Abuchowski et al. 1977).

Furthermore, $0.8 \mathrm{mmol}$ of methoxypolyethylene glycol (M.W. 5,000) was dissolved in $100 \mathrm{ml}$ of dried toluene and activated with $0.9 \mathrm{mmol} 1,1^{\prime}$-carbonyldiimidazole (CDI) from Sigma in the presence of $6.0 \mathrm{~g}$ molecular sieves A4 for $20 \mathrm{~h}$ at room temperature. After the desired reaction time, the mixture was centrifuged to discard the precipitate and precipitated in $300 \mathrm{ml}$ of $n$-hexane. The activation was monitored by TLC (silica gel, eluent: methanol/chloroform 1:6) (Beauchamp 1983; Tondelli 1985). Activations of PEG 1,100 and PEG 2,000 (Fluka) were similarly prepared using the same molar ratio.

B. licheniformis protease solution, $2 \mathrm{ml}\left(1 \mathrm{mg} \mathrm{ml}^{-1}\right.$ protein), was mixed in $100 \mathrm{ml}$ sodium borate buffer $(0.1 \mathrm{M}$; $\mathrm{pH} 9.3$ ) containing $3.0 \mathrm{~g}$ of 2-O-methoxypolyethylene glycol-4,6-dichloro-s-triazine and methoxypolyethylene glycol imidazolyl carbonyl, respectively. The reaction mixture was shaken at room temperature for 2 and $8 \mathrm{~h}$, respectively. After the desired reaction time, the unbound polymer was removed by gel filtration, using a Superdex 200 HiLoad 16/60 column (Amersham Pharmacia, Uppsala, Sweden), and detection at $280 \mathrm{~nm}$ using a phosphate buffer (0.1 M, pH 7.0) as eluent. Modification with PEG 1,100 and PEG 2,000 was similarly prepared using the same molar ratio.

\section{Determination of molecular weight}

Analytical gel filtration was performed on a Superdex 75 HR 10/30 column (Amersham Pharmacia, Uppsala, Sweden), detection at $280 \mathrm{~nm}$ and using a phosphate buffer (0.1 M, pH 7.0) as eluent. Carbonic anhydrase from bovine erythrocytes (M.W. 29,000), albumin, bovine serum (M.W. 66,000), alcohol dehydrogenase from yeast (M.W. 150,000), $\beta$-amylase from sweat potato (M.W. 200,000) and apoferin from horse spleen (M.W. 443,000), all obtained from Sigma, were used for calibration.

\section{Protease activity}

The proteolytic activity of the native enzyme and conjugates was determined using azocasein as substrate. Of the sample, $150 \mu \mathrm{l}$ was mixed with $250 \mu \mathrm{l}$ of a $2 \%$ azocasein solution in phosphate buffer $(25 \mathrm{mM}, \mathrm{pH} 7.5)$. After an incubation time of $30 \mathrm{~min}$ at $37^{\circ} \mathrm{C}$, the reaction was stopped by adding $1.2 \mathrm{ml} 10 \%$ trichloroacetic acid and 
then centrifuged ( $4 \mathrm{~min}, 3,000 \times \mathrm{g}$ ). Of the supernatant, $600 \mu \mathrm{l}$ was added to $700 \mu \mathrm{l}$ of a $1 \mathrm{M} \mathrm{NaOH}$ solution and mixed. The absorbance at $440 \mathrm{~nm}$ was monitored using a Kontron UVIKON 940 spectrometer. One unit of protease activity is defined as the amount of enzyme required to produce an absorbance change of 1.0 in a $1-\mathrm{cm}$ cuvette within a minute. Protein concentration was determined according to Bradford 1976 using bovine serum albumin as standard.

Stability of protease from $B$. licheniformis and conjugates

After different incubation times at $50^{\circ} \mathrm{C}$, the proteolytic activity of the different protease conjugates was assayed to determine the effects of PEG modification on the thermal stability of the enzyme. The compatibilities of the native protease from $B$. licheniformis and its PEG conjugates were tested by incubating in a common detergent formulation for laundry and a commercial preparation for stain removal on woollen carpets, respectively. Therefore, an aqueous solution of $5 \mathrm{mg} \mathrm{ml}^{-1}$ detergent was prepared and the stain removal agent was diluted with a 1:4 ratio with water.

Staining of wool carpet and knitted fabrics

Chocolate milk $\left(10 \mathrm{ml}\right.$, temperature $\left.60^{\circ} \mathrm{C}\right)$ from a beverage machine was brought on a piece of yellow coloured carpet $(12 \times 6 \mathrm{~cm})$ with the aid of a pipette. Knitted wool fabrics were prewashed in a household machine using wash program 7A and IEC standard detergent. The fabrics $(15 \times 15 \mathrm{~cm})$ were stained with spaghetti paste sauce $\left(60^{\circ} \mathrm{C}\right)$ using a spoon to create circular stains with a diameter of approximately $8 \mathrm{~cm}$.

Stains on carpets and fabrics were air dried and aged for another $24 \mathrm{~h}$ at room temperature. The stained fabrics were cut prior to the cleaning procedure. One half was used for cleaning without enzyme, the other, for the cleaning in the presence of PEG conjugated enzyme.

\section{Stain removal}

Stained carpet pieces were first incubated in a Linitester (one piece of carpet/beaker) using $300 \mathrm{ml}, 25 \mathrm{mM}$ borate buffer $\mathrm{pH} 8.5$ containing $5 \mathrm{mM} \mathrm{CaCl}_{2}$ and in the presence and absence of PEG conjugated protease from $B$. licheniformis for $30 \mathrm{~min}$ at $40^{\circ} \mathrm{C}$. Subsequently, the carpets were cleaned using a spray-extraction procedure and water containing $0.5 \mathrm{~g} \mathrm{l}^{-1}$ tergitol $15-\mathrm{S}-12$ non-ionic surfactant after which, the carpet was air dried.

Stained knitted fabrics were washed in a Linitester for $30 \mathrm{~min}$ at $40^{\circ} \mathrm{C}$ using $300 \mathrm{ml}$ standard detergent solution IEC $\left(3 \mathrm{~g} \mathrm{l}^{-1}\right)$ in the presence and absence of PEGconjugated protease from $B$. licheniformis $(0.6 \mathrm{mU}$ against azocasein). After subsequent rinsing in tap water, the fabric was air dried and analysed.
Stain removal was determined by measuring light reflectance of the remaining stains after the cleaning procedure using an X-rite 968 spectrophotometer in combination with QA-Lite software. The impact of enzyme dosage on the cleaning efficiency was determined by calculating the $\Delta E$ value from the obtained $L, a$ and $b$ values from the stains cleaned in the presence and absence of the enzyme system (Harold 1987).

\section{Determination of tensile strength}

Tensile strength of yarns from washed fabrics has been measured according to ISO 2062 using a Hounsfield tensile tester.

Treatment of the wool fibres

The optimum incubation conditions to determine the enzymatic effect were determined by using an experimental design with four factors (agitation speed, component ratio, enzyme activity and incubation time) at four different levels, varying from 0 to 5.5 (agitation), from 0 to 4 (ratio), from 0 to 4 (activity) and from 0 to 5.5 (time) based on a Central Composite statistical design. The effects and interactions of the various factors studied and the combinations thereof which showed the best results for the weight loss were calculated using the Design Expert 6.0 computer software programme (StateEase, Minnesota, USA).

Wool fibres, pre-tempered for $10 \mathrm{~min}$ at $50^{\circ} \mathrm{C}$, were incubated in sodium borate buffer $(25 \mathrm{mM} ; \mathrm{pH} 8.5)$ at $50^{\circ} \mathrm{C}$ at different ratio, enzyme concentration, incubation time and agitation level according to the experimental design. The enzyme in the incubation mixture was inactivated by raising the temperature to $70^{\circ} \mathrm{C}$ for a further $20 \mathrm{~min}$ without agitation.

After rinsing the sample three times with $30 \mathrm{ml}$ of distilled water the fibres were air dried. The weight loss of enzyme-treated wool fabrics was elaborated by using an electronic balance after conditioning for $24 \mathrm{~h}$ in a desiccator.

\section{Results}

Synthesis of the $B$. licheniformis protease-PEG conjugates

PEG has to be "activated" prior to the coupling to proteins and two different strategies for PEG activation were compared in this study. The first used cyanuric chloride for PEG activation resulting in 2-O-methoxypolyethylene glycol-4,6-dichloro-s-triazine and in the second, 1,1'carbonyldiimidazole was used resulting in an imidazole carbamate derivative.

For both activation strategies, protease activity in the fractions collected after gel filtration of the modified 
proteases shifted towards shorter retention times confirming thereby an increased molecular weight compared to the native enzyme. Thus, the increase of molecular weight due to attachment of the PEG was successful. Furthermore, the absence of native enzyme in the gel filtration pattern after the modification reaction indicated a quantitative coupling of the enzyme to the activated PEG polymer. Whereas the 2-( $O$-methoxypolyethylene glycol)-4,6-dichloro-s-triazine of modification procedure led to serious deactivation of the $B$. licheniformis protease, most of the activity on azocasein was recovered using methoxypolyethylene glycol imidazolyl carbonyl (Table 1). The size of the PEG molecules used for the modification correlated with the apparent molecular size of the resulting PEG-modified proteases. The molecular weight of the protease could be doubled and even increased ten times using 1.1 and $5 \mathrm{kDa}$ methoxypolyethylene glycol, respectively.

\section{Stability of PEG modified proteases}

The compatibilities of the native protease from $B$. licheniformis and its PEG conjugates with different commercial detergent formulations were tested by incubation in aqueous detergent solutions at $50^{\circ} \mathrm{C}$. Azocasein was used as a model substrate for stain removal activity due to enzymatic hydrolysis. The half-life times of the $2.0 \mathrm{kDa}$ and the $5.0 \mathrm{kDa}$ protease conjugates from $B$. licheniformis in this detergent mixture were above $1 \mathrm{~h}$ while the remaining activity of the native enzyme after 1-h incubation was only $25 \%$ of its initial activity (Fig. 1).

\section{Stain removal}

Different enzymes and their conjugates from $B$. licheniformis and B. lentus were tested, respectively. In contrast to the PEG conjugate from $B$. lentus which was not suitable for stain removal (data not shown), the modified protease from $B$. licheniformis showed a significant contribution to the stain removal from woolen fabrics and carpet. Destaining of spaghetti stains from fabrics with 5 and $2 \mathrm{kDa}$ modified proteases resulted in $\Delta E$ values of 9 and 15, respectively. Enzymatic destaining of chocolate milk stains from carpets had best results with the $2-\mathrm{kDa}$

Table 1 Synthesis of $B$. licheniformis protease conjugates with 2$O$-methoxypolyethylene glycol-4,6-dichloro-s-triazine (CC) and methoxypolyethylene glycol imidazolyl carbonyl, respectively (CDI) (M.W. 5000) using different molar ratios of activated polymer to enzyme

\begin{tabular}{lll}
\hline $\begin{array}{l}\text { Molar } \\
\text { ratio }\end{array}$ & $\begin{array}{l}\text { Activity recovery (\%) using } \\
\text { CC activated PEG }\end{array}$ & $\begin{array}{l}\text { Activity recovery (\%) using } \\
\text { CDI activated PEG }\end{array}$ \\
\hline 32 & 75 & 95 \\
108 & 70 & 90 \\
216 & 50 & 90 \\
\hline
\end{tabular}

The activity recovery indicates the difference of activity before and after the modification reaction



Fig. 1 Proteolytic activity of native and modified protease from $B$. licheniformis in the presence of detergent. The enzyme solutions were incubated at $50^{\circ} \mathrm{C}$ in a detergent formulation $\left(5 \mathrm{mg} \mathrm{ml}^{-1}\right)$ at equal amounts of native enzyme (•), conjugate with PEG $1.1 \mathrm{kDa}$ $(\bullet), 2.0 \mathrm{kDa}(\bullet)$ and $5.0 \mathrm{kDa}(\times)$

modified proteases and gave $\Delta E$ values 3. Thereby, a higher activity towards the chocolate stains was observed for the protease modified with 2-kDa PEG compared to the 5-kDa PEG (the dosage of 5-kDa PEG modified enzyme required to obtain comparable performance level is approximately twice that of 2-kDa PEG modified enzyme). No difference of the tensile strength of fibres from both, enzyme treated and non-enzyme treated fabrics, after the stain removal experiments could be detected.

\section{Enzymatic treatment of wool fibres}

To allow comparison of the destructive effect of modified and native $B$. licheniformis protease towards protein fibres, optimum conditions for the hydrolysis of wool by this protease were determined (worst-case scenario). To determine these optimum incubation conditions, an experimental design with four factors (agitation speed, liquid ratio component, enzyme activity and incubation time) at four different levels, varying from 0 to $300 \mathrm{rpm}$ (agitation), from $1: 100$ to $1: 500$ (ratio), from 0 to $20 \mathrm{U}$ (activity), and from 0 to 330 min (time) based on a Central Composite statistical design was followed. The plot of the predicted vs the laboratory values is represented in Fig. 2a. The suggested linear model fits well for obtained values and the Model F-value of 15.00 implies that the model is significant. In this case component ratio, enzyme activity and incubation time are significant model terms, and no interaction between the different factors is present.

One might attribute from the model, two different effects for weight loss during the incubation, on one hand the mechanical abrasion and on the other the enzymatic hydrolysis. In Fig. 2b, the impact of mechanical force is illustrated by the agitation and ratio. Whereas increasing the input of energy (high agitation) caused an increased weight loss, high ratio showed a depressant effect of the water. The factors, incubation time and activity dosed, played a major role. 
a

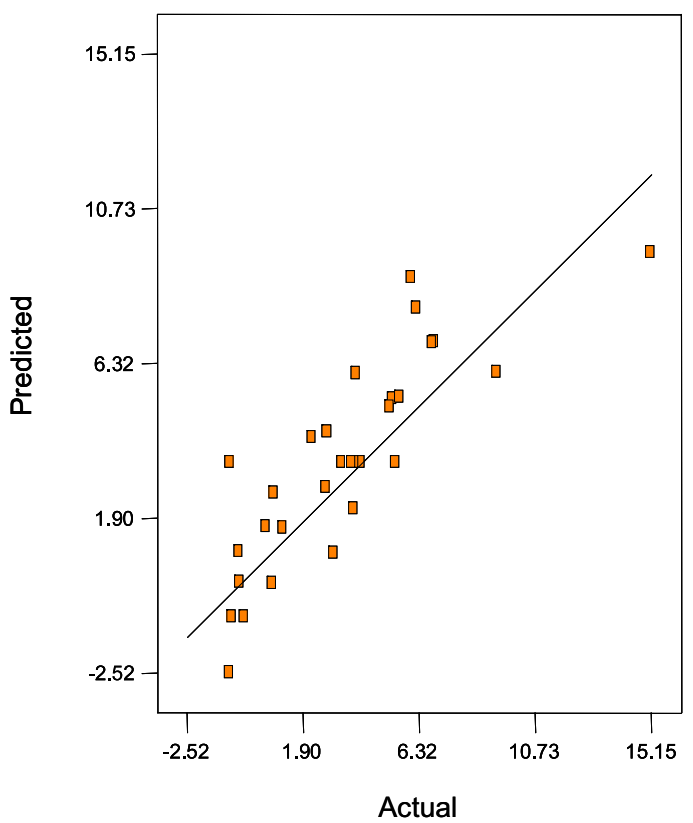

b

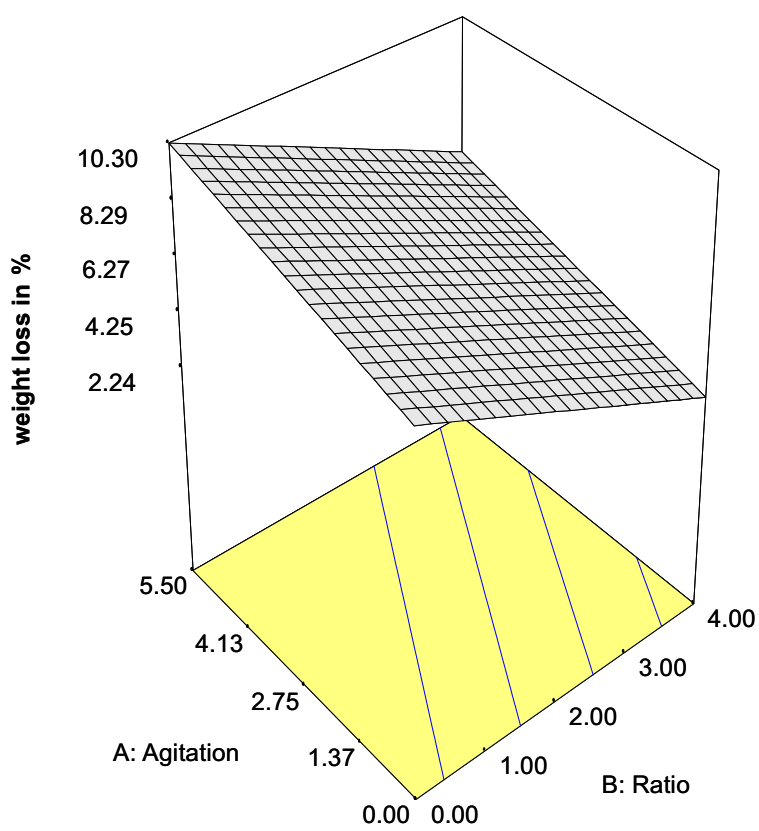

Fig. 2 Optimization of wool treatment with a protease from $B$. licheniformisa Predicted vs actual data, b Two dimensional plot weight loss in percent vs agitation level and ratio (the values in the $x$ and $y$ axes are coded values)

At these optimum conditions for wool hydrolysis, fabrics were incubated with native and modified protease from $B$. licheniformis at the same level of activity against azocasein. Hydrolysis of wool with native enzyme resulted in severe damage of the fibres and high weight losses $(16 \%)$ while covalent attachment of polyethylene glycol onto the enzyme resulted in protection of fibres against damage (Figs. 3 and 4).

\section{Discussion}

Two different strategies for the covalent attachment of PEG to a protease from $B$. licheniformis were compared to produce enzymes for protein stain removal from wool

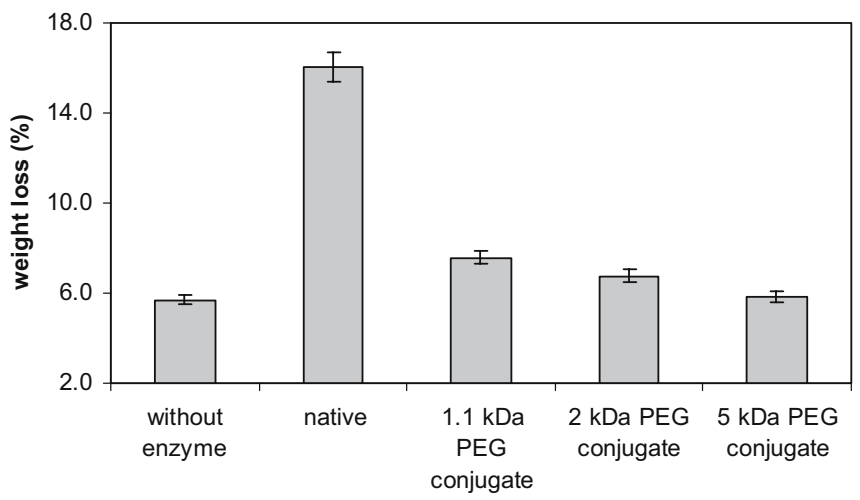

Fig. 3 Weight losses (percentage of its original weight) after treatment of wool fibres with protease from Bacillus licheniformis modified with different sized polyethylene glycol resulting in enzyme conjugates with different molecular weights materials. First, the replacement of one chlorine atom of triazine with the terminal hydroxyl group of the PEG chain resulting in 2-(O-methoxypolyethylene glycol)-4,6dichloro-s-triazine was studied. In general, due to the two remaining chlorine atoms, the activated polymer is enabled to react with the $\varepsilon$-amino group of lysine residues on the surface of the enzyme (Inada et al. 1995; Abuchowski et al. 1977).

The expected product in the second activation using $1,1^{\prime}$ carbonyldiimidazole is an imidazole carbamate derivative. This product was successfully purified by repeated precipitation in $n$-hexane instead of the dialysis described in the literature (Beauchamp 1983). In our study, only the second strategy leads to conjugates with high activity recovery of up to $95 \%$.

The loss of enzyme activity after attachment to 2-Omethoxypolyethylene glycol-4,6-dichloro-s-triazine activation could be due to reaction of this compound with sulfhydryl groups of the enzyme. In contrast with CDI activation, a certain selectivity in the conjugation can be achieved due to a lower reaction rate of the acylating reaction which might explain the higher activity recovery found in this study (Veronese 2001; Yoshinga and Harris 1989). However, the modification strategy choice seems to depend strongly on the enzyme used. While a protease of $B$. lentus was successfully modified with $2-(O-$ methoxypolyethylene glycol)-4,6-dichloro-s-triazine and retained up to $80 \%$ of its initial activity (Schroeder et al. 2004), this was not the case for the protease of $B$. licheniformis investigated in this study.

A detergent enzyme should have good temperature stability and should be active over a longer period of time. Interestingly, after PEG modification, the stability of the $B$. 
Fig. 4 SEM images after enzymatic treatment of wool fibres with native protease from Bacillus licheniformis [left (a)] and modified enzyme [right: (b)]
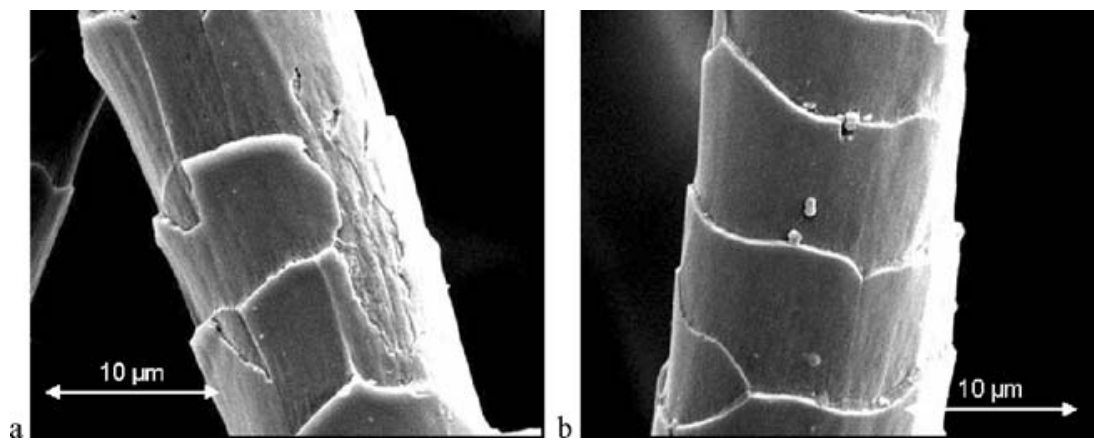

licheniformis protease conjugates increased with the molecular weight of the PEG chain attached onto the enzyme. The conjugates were generally more stable than the native unmodified enzyme when incubated in a detergent solution. Although only few is known in the literature about stabilities of PEG-modified enzymes in detergent formulations, enhanced stability (in buffer) of PEG-trypsin was reported previously by Gaertner and Puigserver (1992). These authors ascribed the stability increase to the formation of a highly hydrogen-bonded structure around the enzyme caused by the long PEG chains. A household machine washing program normally takes 60 to $90 \mathrm{~min}$; therefore, the activity of the added enzyme should remain high over a substantial part of such period (Banik and Prakash 2004). The $2.0 \mathrm{kDa}$ and the $5.0 \mathrm{kDa}$ protease conjugates from $B$. licheniformis retained $50 \%$ of the initial proteolytic activity after $1 \mathrm{~h}$, and hence, showed their suitability as potential additives in a detergent formulation. Stoner et al. 2004 reported recently that the loss of proteolytic activity in detergents is caused by autolysis. Protection towards auto-degradation can be achieved by chemical modification (Yang et al. 1996), whereas the impact increases with higher molecular weight of the attached polymer.

The application of the $B$. licheniformis protease conjugates as a detergent additive was studied using white wool fabrics stained with spaghetti sauce and yellow woollen carpet stained with chocolate milk, respectively. These protease sensitive stains were recommended by a carpet cleaner (James, Grubbenvorst, The Netherlands) specialising in wool fabrics and carpets. Stain removal was quantified with the $\Delta E$ value which represents the shift of the coordinates of the colour in the cylindrical colour space $L^{*}, a^{*}$ and $b^{*}$, based on the theory that colour is perceived by black-white $(L)$, red-green $(a)$ and yellow-blue $(b)$ sensations (Harold 1987). Based on the $\Delta E$ values, treatment with PEG modified protease from $B$. licheniformis showed a high potential for stain removal from both woolen fabrics and carpet. In contrast, we did not measure any destaining effect with PEG modified proteases from $B$. lentus although these enzymes were able to partially hydrolyse wool cuticles resulting in a wool anti-shrinking effect (Schroeder et al. 2004).

In general, PEG modification can restrict the access of the enzyme to substrates due to sterical hindrance or limitation of diffusion into fibrous materials. For this particular application in the destaining of protein materials, PEG modification should limit diffusion of the enzymes into wool fibres and prevent hydrolysis of these, while other macromolecular protein materials contained in stains should remain accessible to the enzyme. Thus, in the second phase, the effect of PEG modification of $B$. licheniformis protease on wool hydrolysis was studied in more detail.

Enzymatic hydrolysis of wool fibres is affected by different factors such as nature and ionic strength of the treatment buffer (Shen et al. 1999) and enzyme activity and incubation time (Stanescu et al. 2002). Furthermore, the process depends on adsorption and desorption of the enzymes which can result in a nonuniform treatment (Riva et al. 1993). In addition, for weight loss during incubation, mechanical abrasion has to be considered. To elaborate only the enzymatic effects for wool treatment, the incubation was performed only with gentle agitation.

Treating the wool fibres with native protease resulted in severe damage of the fibres and unacceptable high weight losses, conforming previous results (Riva et al. 1993) for high enzyme concentrations. Recently, a successful restriction of the hydrolysis of wool fibres to cuticles was shown, resulting in $90 \%$ decrease of the weight loss compared to non-modified enzymes (Schroeder et al. 2004). These moderate proteolytic reaction and low damages were in correlation with decreased enzyme diffusion into the fibres. Similar studies confirmed these results (Silva et al. 2005). However, the current study showed that an optimal modification of the protease can only be found in a balance between small polymer chain for good stain removal properties and long polymer chain restricting the damage of wool fibres and increasing half life. Therefore, a consensus could be reached modifying a protease from $B$. licheniformis with a $2-\mathrm{kDa}$ methoxy polyethylene glycol. Such enzymes do not only have a high potential as constituents of detergents for woolen cloth but also for carpet cleaning agents improving hygienic aspects and lifetime of these materials.

Acknowledgement We would like to thank the European Commission 'Competitive and Sustainable Growth' GRD-CT-200200695 for their financial support of this project. 


\section{References}

Abuchowski A, van Es T, Palczuk NC, Davis FF (1977) Alteration of immunological properties of bovine serum albumin by covalent attachment of polyethylene glycol. J Biol Chem 252:3578

Banik RM, Prakash M (2004) Laundry detergent compatibility of the alkaline protease from Bacillus cereus. Microb Res 159:135-140

Beauchamp CO, Gonias SL, Menapace DP, Pizzo SV (1983) A new procedure for the synthesis of polyethylene glycol-protein adducts, effects on function, receptor recognition, and clearance of superoxide dismutase, lactoferrin, and alpha 2-macroglobulin. Anal Biochem 131:25-33

Besson C, Favre-Bovine G, O'Fagain C, Wallach J (1995) Chemical derivates of Pseudomonas aeruginosa elastase showing increased stability. Enzyme Microb Technol 17:877-881

Bradford MM (1976) A rapid and sensitive method for the quantitation of microgram quantities of protein utilizing the principle of protein-dye binding. Anal Biochem 72:248-254

Dosio F, Apricco S, Brusa P, Stella B, Cattel L (2001) Poly(ethylene glycol)-human serum albumin-paclitaxel conjugates: preparation, characterization and pharmacokinetics. J Control Release 76:107-117

Egmont MR (2005) Application of proteases in detergents. In: Van Ee J, Misset O, Baas EJ (eds) Enzymes in detergents. Marcel Dekker, New York, pp 61-74

Gaertner HF, Puigserver AJ (1992) Increased activity and stability of poly(ethylene glycol)-modified trypsin. Enzyme Microb Technol 14:150-155

Galante YM, Formantici C (2003) Enzyme applications in detergency and in manufacturing industries. Curr Org Chem 7:1399-1422

Harold RW (1987) Textiles: appearance, analysis and shade sorting. Text Chem Color 19:23-31

Heine E, Höcker H (1995) Enzyme treatments for wool and cotton. Rev Prog Coloration 25:57-63

Hernáiz MJ, Sánchez-Montero JM, Sinisterra JV (1997) Influence of the nature of modifier in the enzymatic activity of chemical modified semipurified lipase from Candia rugosa. Biotechnol Bioeng 55:252-260

Inada Y, Furukawa M, Sasaki H, Kodera Y, Hiroto M, Nishimura H, Matsushima A (1995) Biomedical and biotechnological applications of PEG- and PM-modified proteins. Trends Biotechnol 13:86-91
Kodera Y, Matsushima A, Hiroto M, Nishimura H, Ishii A, Ueno T, Inada Y (1998) Pegylation of proteins and bioactive substances for medical and technical applications. Progr Polymer Sci $23: 1233-1271$

Koops BC, Verheij HM, Slotboom AJ, Egmond MR (1999) Effect of chemical modification on the activity of lipases in organic solvents. Enzyme Microb Technol 25:622-631

Kwon OH, Imanishi Y, Ito Y (1999) Catalytic activity and conformation of chemically modified subtilisin Carlsberg in organic media. Biotechnol Bioeng 66:265-270

Maurer KH (2004) Detergent proteases. Curr Opin Biotechnol $15: 330-334$

Riva A, Cegarra J, Prieto R (1993) The role of an enzyme in reducing wool shrinkage. J Soc Dyers Colour 109:210-213

Roberts MJ, Bentley MD, Harris JM (2002) Chemistry for peptide and protein PEGylation. Adv Drug Deliv Rev 54:459-476

Schroeder M, Schweitzer M, Lenting HBM, Gübitz GM (2004) Chemical modification of proteases for wool cuticle scale removal. Biocatal Biotransform 22:299-305

Shen J, Bishop DP, Heine E, Hollfelder B (1999) Some factors affecting the control of proteolitic enzyme reactions on wool. J Textile Inst 90:404-411

Silva CJSM, Prabaharan M, Gübitz GM, Cavaco-Paulo A (2005) Treatment of wool fibres with subtilisin and subtilisin-PEG. Enzyme Microb Technol 36:917-922

Stanescu MD, Bucur MS, Pustianu M, Mihuta S, Raileanu M, Sauri R, Juliá MR, Erra P (2002) A comparative study of two enzyme treatments. Indian J Fibre Text Res 27:408-416

Stoner MR, Douglas DA, Gualfetti PJ, Becker T, Manning MC, Carpenter JF, Randolph TW (2004) Protease autolysis in heavyduty liquid detergent formulations: effects of thermodynamic stabilizers and protease inhibitors. Enzyme Microb Technol 34:114-125

Tondelli L, Laus M, Angeloni AS, Ferruti P (1985) Poly(ethylene glycol) imidazolyl formats as oligomeric drug-binding matrices. J Control Release 1:251-257

Veronese FM (2001) Peptide and protein PEGylation: a review of problems and solutions. Biomaterials 22:405-417

Yang Z, Domach M, Auger R, Yang FX, Russell AJ (1996) Polyethylene glycol-induced stabilization of subtilisin. Enzyme Microb Technol 18:82-89

Yoshinga K, Harris JM (1989) Effects of coupling chemistry on the activity of poly(ethylene glycol)-modified alkaline phosphatase. J Bioact Compat Polym 4:17-24 